\title{
Inconsistencies among secondary sources of chukar partridge (Alectoris chukar) introductions to the United States
}

Michael P Moulton, Wendell P Cropper, Jr, Andrew J Broz

An important source of information concerning the fates of intentionally introduced exotic bird species has been collections of historical data that sometimes include species released, numbers released, locations of release, and establishment success. These data have been used to assess potential predictors of establishment success such as propagule pressure, site-level factors, and species characteristics. In order to better understand the limitations of such historical compilations, we compared data for the Chukar (Alectoris chukar) introductions to the USA from two often used secondary compilations with a more comprehensive source (Christensen (1970)... We found that the major compilations of Long (1981) and Lever (1987) are inconsistent and likely to be incomplete, and inaccurate, in terms of the taxa introduced, the numbers introduced, and the fates of these introductions. Propagule pressure analyses have often assumed that every bird in every release must be summed to represent the propagule pressure necessary for establishment. We found, however, that large numbers of birds were released into states and counties with already established populations. Additionally, in numerous states very large numbers of Chukars were unsuccessfully released. We conclude that site-level factors were more important influences of establishment success than propagule pressure was. 
1 Inconsistencies Among Secondary Sources of Chukar Partridge (Alectoris chukar)

2

3

4

5

6

7

8

9

10

11

12

13

14

15

16

17

18 Gainesville, FL 32611-0410; <wcropper@ufl.edu>

\section{Introductions to the United States.}

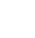

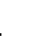

5

6

(1)

9

0

1

3

${ }^{1}$ Michael P. Moulton, ${ }^{2}$ Wendell P. Cropper, Jr., and ${ }^{1}$ Andrew J. Broz

$5{ }^{1}$ Department of Wildlife Ecology and Conservation; University of Florida; PO Box 110430; Gainesville, FL 32611-0430; <moultonm@ufl.edu>

$17{ }^{2}$ School of Forest Resources and Conservation; University of Florida; PO Box 110410;

19 


\section{Abstract}

An important source of information concerning the fates of intentionally introduced

22 exotic bird species has been collections of historical data that sometimes include species

23 released, numbers released, locations of release, and establishment success. These data

24 have been used to assess potential predictors of establishment success such as propagule

25 pressure, site-level factors, and species characteristics. In order to better understand the

26 limitations of such historical compilations, we compared data for the Chukar (Alectoris

27 chukar) introductions to the USA from two often used secondary compilations with a more

28 comprehensive source (Christensen (1970)... We found that the major compilations of

29 Long (1981) and Lever (1987) are inconsistent and likely to be incomplete, and inaccurate,

30 in terms of the taxa introduced, the numbers introduced, and the fates of these

31 introductions. Propagule pressure analyses have often assumed that every bird in every

32 release must be summed to represent the propagule pressure necessary for establishment.

33 We found, however, that large numbers of birds were released into states and counties

34 with already established populations. Additionally, in numerous states very large numbers

35 of Chukars were unsuccessfully released. We conclude that site-level factors were more

36 important influences of establishment success than propagule pressure was.

\section{Introduction}


In attempting to identify the processes that deter or promote establishment of

43 introduced bird populations, several empirical studies have concluded that propagule

44 pressure, meaning the total number of individuals of a species released in some place, is the

45 principal determining factor (e.g. Newsome and Noble 1986; Veltman et al. 1996; Duncan

46 1997; Green 1997; Cassey et al. 2004; Lockwood et al. 2005; Sol et al. 2012). Although this

47 conclusion has been repeatedly criticized (Moulton et al. 2010, 2011, 2012a,b, 2013;

48 Moulton and Cropper 2014a,b, 2015), and recent studies have emphasized the importance

49 of species-level characteristics over propagule pressure (e.g. Sol et al. 2012; Cassey et al.

50 2014), some have persisted in touting its primary importance (e.g. Blackburn et al. 2015a,

51 b).

At the same time, site-level factors have largely been ignored by proponents of

propagule pressure, despite numerous studies that have shown their importance in bird introductions (e.g. Gullion 1965; Diamond and Veitch 1981; Griffith et al. 1989; Moulton and Pimm 1983, 1987; Lockwood et al. 1993; Lockwood and Moulton 1994; Smallwood 1994; Case 1996; Gamarra et al. 2005; Moulton and Cropper 2014b; Allen et al. 2015).

A principal basis for the propagule pressure hypothesis, as applied to birds, has

been compilations of historical records such as those by Thomson (1922), Phillips (1928) Long (1981) Lever $(1987,2005)$. In relying on such secondary sources, studies that claim to support propagule pressure make two assumptions: first that the chronicle of introductions presented in these sources is complete and accurate; and second that the

62 principal, if not sole, motivation behind the introductions was the establishment of selfsustaining populations. A corollary to this second assumption is that introductions would 64 end once it was perceived that the species was established. We show that for Chukar 
65 (Alectoris chukar) introductions to the USA these assumptions are unmet, and we provide

66 evidence that introduction outcomes in Chukars are likely to be mostly influenced by

67 factors other than numbers released.

68 Our initial motivation for conducting this study came from the observation that the

69 compilations of Long (1981) and Lever (1987) often were quite different from that of

70 Christensen (1970), although both cited Christensen (1970) in their treatments of the

71 Chukar. Long (1981) referred to the species as Alectoris graeca but makes it clear that the

72 subspecies involved in the USA were in fact Chukars (Asian origin) and not Rock Partridges

73 (European origin). Lever (1987) noted that 'Greek Chukars' released in California were

74 likely Rock Partridges. Christensen (1970) discussed the difference in nomenclature

75 referring to North American introductions as Alectoris chukar, following the work of

76 Watson (1962a,b). Lever (1987) also noted that the species was Alectoris chukar, and

77 suggested that the so-called 'Greek Chukars' presented to the state of California were

78 actually Rock Partridges (Alectoris graeca).

Historical compilations of bird introductions have often (see above) been used to assess some factors believed to be associated with successful introductions. It is, at least

81 implicitly, assumed that the historical records are either accurate, or that the errors do not

82 significantly bias these analyses. It is difficult to know how complete multi-decade old

83 records actually are, but it is possible to assess the consistency of the major compilations

84 and of the published analyses that have relied on these sources.

\section{Methods and Materials}

To illustrate the hazards in depending on secondary sources, we analyzed historical

87 records of introductions of the Chukar to the United States as reported in two major 
88 secondary sources: Long (1981) and Lever (1987). We then compare the compilations in

89 these two references to the records reported by Christensen (1970) and then we show how

90 they compare to the records used in a recent study (Sol et al. 2012). Christensen (1970)

91 based his compilation on two separate surveys using questionnaires sent to state wildlife

92 agencies once in the early 1950s and again in the late 1960s. As such we assume it is the

93 more accurate reflection of the true record of Chukar introductions in the USA.

94 The Chukar has a vast range throughout Asia (Watson 1962a), and was once

95 considered a subspecies of the Rock Partridge (Alectoris graeca), which occurs in Europe.

96 Watson (1962a,b) showed that subtle but consistent morphological differences exist

97 between adjacent populations of $A$. graeca and $A$. chukar in extreme Eastern Europe. We

98 follow the 4th edition of the Howard and Moore Checklist of Birds of the World (Dickinson

99 and Remsen 2013), which also treats the two as distinct species.

100 We compiled lists of introduction records per state as reported by Long (1981) and

101 Lever (1987). We then compared these lists to Christensen $(1970,1996)$. We compared

102 the number of individuals released in the states for which all three references reported a

103 total number of individuals released. We transformed the total numbers by calculating

104 their common logarithms and then compared these values using a generalized linear mixed

105 model with state (location) of the introduction as a random factor and the three references

106 as a fixed effect. We used the SAS Glimmix procedure (SAS 2009) for our analyses.

107 We then compare Christensen's (1970) list to the records used in the recent study of

108 introductions by Sol et al. (2012) and show their degree of reliance on the work of Long

109 (1981) and Lever (1987), but not on the seemingly more complete work of Christensen

110 (1970). 


\section{Results}

112 Bump (1951) claimed that Chukars had likely been released in every one of the 48

113 states in the US (Alaska and Hawaii did not become states until 1959) but none of the

114 historical references (Long 1981; Lever 1987; Christensen 1970) listed releases for all 48

115 states. Christensen $(1970,1996)$ reported Chukar releases to 40 of the conterminous 48

116 states (he also noted introductions to Hawaii and Alaska) and listed the total number of

117 individuals released in 35 states (Figure 1). For five other states (Florida, Louisiana,

118 Michigan, Mississippi, and Rhode Island) respondents reported to Christensen (1970) only

119 that a "few" individuals had been released (Table 1). Long (1981) reported introductions

120 of Chukars to just 22 states, but only listed propagule information for 16 states. Lever

121 (1987) listed releases of Chukars to 30 states, but only reported propagule information for 12218 states.

123 Although Long (1981) and Lever (1987) both cited Christensen (1970), neither

124 followed his compilation very closely. The reasons that Long (1981) and Lever (1987)

125 excluded data for so many of the states listed by Christensen (1970) are unknown.

126 Moreover, regarding the 15 states for which all three references listed propagule

127 information, Long (1981) reported the same number listed by Christensen (1970), for only

128 one state (Missouri) and Lever (1987) did not report the same number as Christensen

129 (1970) for any state.

130 Long (1981) and Lever (1987), both reported numbers for New York, although

131 Christensen (1970) did not. Likely this is due at least in part to Christensen's (1970)

132 report being based on wildlife agency surveys and apparently does not include any private 
133 releases. Lever (1987) also reported numbers for Nebraska and Utah, as did Christensen

134 (1970), but not Long (1981).

135 In our mixed linear model the logarithms of the numbers of individuals released

136 across the three references and 15 states, with state of introduction as a random effect and

137 reference as a fixed effect, differed significantly in a Type III test (df. 2, 20; F = 4.94; $\mathrm{p}=$

138 0.014). Clearly, most of the variation in numbers released was due to the higher numbers

139 Christensen (1970) reported.

140 Thus, for unknown reasons, Long (1981) and Lever (1987) included only about half

141 the states, and significantly fewer individuals than Christensen (1970). We emphasize that

142 none of these references was compiled for the purpose of testing the propagule pressure

143 hypothesis. Nevertheless, we must conclude that results of any studies involving the

144 Chukar that relied heavily on either Long (1981) or Lever (1987) would likely be based on

145 incomplete and inaccurate information and therefore are suspect.

146 Studies that presumably include Chukar releases to the USA (e.g. Cassey et al. 2004)

147 do not always make their data available. One exception to this is the recent study (Sol et al.

148 2012), which involved a global analysis aimed at disentangling the effects of species-level

149 characters on introduction success in birds. Sol et al. (2012) claim to have updated the

150 database used by Cassey et al. (2004).

151 We were able to match 38 of 40 records of Chukars reported by Sol et al. (2012),

152 using their propagule sizes and ID numbers, to reports by Long (1981) or Lever (1987) for

15316 (or 17) states in the USA (Table 2). Sol et al. (2012) did not specify individual states in

154 their records, but we surmise that they included multiple releases to Arizona (2), California 
155 (8), and Utah (14), and single releases (sums) for 13 (or 14 -- see New York discussion 156 below) others.

157 Sol et al. (2012) listed an unsuccessful record of a propagule size of 175 (Sol et al. ID 158 \# - 61), but neither Long (1981) nor Lever (1987) listed a propagule of this size. It is 159 possible that this represents a conflation of the record Long (1981) and Lever (1987) listed 160 for Delaware County, New York where 25-150 individuals were released yearly between 1611936 and 1939. As shown in Table 2, this record in Sol et al. (2012) falls exactly between 162 values and ID numbers we matched to Lever (1987) for Missouri (1900 - Sol et al. ID \# 60) 163 and Pennsylvania (2021 - Sol et al. ID \# 62). If this record is actually for New York it 164 would represent the fourteenth state as noted above.

165 Sol et al. (2012) also listed two unsuccessful releases of 17 individuals each. One of 166 these possibly refers to 17 individuals released in Alaska (Lever 1987) but the other is 167 uncertain. Lever (1987) listed releases to 17 counties in Nebraska of 27842, and it is 168 possible that Sol et al. (2012) in the course of updating the data inadvertently included this 169 as a separate release.

170 We summed multiple releases for Arizona, California and Utah listed by Sol et al.

171 (2012) to make their records comparable to the work of Christensen (1970) Long (1981)

172 and Lever (1987). In a separate mixed model again with state of introduction a random

173 effect and log number of individuals released, we observed a highly significant difference in $174 \log$ number after controlling the random effect of state in the Type III test of fixed effects (F $1753,45=5.88 ; \mathrm{p}>\mathrm{F}=0.002$ ).

176 We further compared subsets of the sources using two orthogonal contrasts. First, 177 we compared the numbers that Christensen (1970) reported per state to those reported by 
178 the combination of Long (1981), Lever (1987), and Sol et al. (2012). In this contrast we

179 observed a significant difference $(t=16.60 ; p>t=0.0002 ; d f=45)$. Next we compared the

180 combination of Long (1981) and Lever (1987) versus Sol et al. (2012), and here the

181 contrast was not significant $(\mathrm{t}=1.01 ; \mathrm{p}>\mathrm{t}=-0.32 ; \mathrm{df}=45)$.

\section{Discussion}

The first assumption of the propagule pressure hypothesis mentioned above was

184 that the historical record was complete and accurate. Whereas there might be more complete and accurate records that are not generally well known, secondary sources such as Long (1981) and Lever (1987) are seemingly incomplete and likely inaccurate. Studies such as Sol et al. (2012) and presumably Cassey et al. (2004) apparently relied heavily on the reports in Lever (1987) and Long (1981) but as we have shown here neither author completely or accurately reflected the introduction data presented by Christensen (1970).

Thus, for Chukar introductions to the USA we have shown that the record as presented by Long (1981) and Lever (1987) appears to be incomplete and inaccurate. necessary for establishment. Chukars currently have self-sustaining populations in ten western states (see Table 1). In four of these states (California, Idaho, Nevada, and other six states (Arizona, Colorado, Montana, Oregon, Utah, and Wyoming) the status was considered uncertain, doubtful (Arizona) or hopeful (Utah, Oregon). However, additional

198 individuals were released in all ten states between 1954 and 1970 (Christensen 1970), 199 strongly suggesting that establishment of wild Chukar populations was not the only goal. -

200 +If propagule pressure was assessed as an essential factor by the professionals introducing 
201 these birds, we might expect the six states where the status was uncertain to release larger 202 numbers after 1954 than the four states where the Chukar was considered established. As

203 indicated in Table 1, Christensen (1954) considered Chukars to be established in four

204 states (California, Idaho, Nevada, and Washington). However, by 1970 additional

205 individuals were released in all four states (California - 10,446; Idaho - 17,129; Nevada -

206 7256; Washington - 43879). Thus, even in those states where the population of Chukars

207 was considered established, releases continued. In fact, introductions continued for years

208 after Christensen's (1970) report. Thus, 'Banks (1981) further reported that in the state of

209 Washington where the Chukar was considered established by 1954 , more than 51,000

210 Chukars were released between 1970 and 1978.

211 As noted by Duncan et al. (2003) three levels of factors could influence introduction

212 outcome in birds: species-level; event-level; and site-level. As we focus here solely on

213 Alectoris chukar, we can ignore the possibility that species-level differences could explain

214 differences in introduction outcomes. Could other event-level characteristics be

215 responsible? Possible event-level factors, other than propagule pressure, include

216 characteristics of the releases themselves. Some studies (e.g. Veltman et al. 1996; Sol et al.

217 2012), include releases of diverse sets of species that likely were made under differing

218 circumstances, and with different goals. For example, the conditions involved in releases of

219 species introduced for biological control likely differed from those of species released for

220 aesthetic reasons. Such diverse releases likely were made by groups or individuals with

221 different goals. We note that the Chukars were introduced chiefly, if not exclusively, to

222 provide recreational hunting opportunities. The numbers of individuals released in the

223 different states, reported by Christensen (1970) came from questionnaires sent to state 
224 game and fish departments throughout the USA. The Chukar releases Christensen (1970)

225 reported were presumably all made by state sponsored professional wildlife scientists and

226 so it is unlikely that differences in introduction outcomes across the states could simply

227 reflect differences in the levels of competence among personnel in the different states.

228 Despite the seeming homogeneity in Chukar introduction practices, in several states very

229 large numbers of Chukars were unsuccessfully released. For example, 85,000 individuals

230 were released into Minnesota, more than 43,000 into Wisconsin, and more than 28,000 in

231 Nebraska, only to fail.

232 The results here strongly imply that factors other than sheer numbers, and

233 characteristics of the release events determined the outcome of Chukar introductions.

234 Thus, the logical explanation is that site-level factors such as climate (e.g. Tomlinson 1960)

235 or habitat characteristics (Gullion 1965) were of greater importance than sheer numbers in

236 determining the outcome of Chukar introductions. Indeed, the only states with successful

237 Chukar populations are states that straddle or are west of the continental divide. These

238 states share certain environmental characteristics: all are more arid and mountainous than

239 states where Chukars failed (Johnsgard 1988, Christensen 1996). 


\section{References}

249 Allen CR, Angeler DG, Moulton MP, Holling CS (2015) The importance of scaling for

250 detecting community patterns: success and failure in assemblages of introduced

$251 \quad$ species. Diversity 7: 229-241, doi:10.3390/d70x000x

252 Banks RC (1981) Summary of foreign game bird liberations, 1969-1978. USDI, Fish and

253 Wildlife Service, Special Scientific Report--Wildlife No. 239

254 Blackburn TM, Lockwood JL, Cassey P (2015a) The influence of numbers of invasion success. Molecular Ecology 24: 1942-1953, DOI: 10.1111/mec.13075

Blackburn TM, Dyer E, Su S, Cassey P (2015b) Long after the event, or four things we (should) know about bird invasions. J. Ornithology, DOI 10.1007/s10336-015-1155-

z, published online 18 February 2015

Bump G (1951) Game introductions--when, where, and how. Trans N. Am. Wild. Conf. 16: 316-325

261 Case T (1996) Global patterns in the establishment and distribution of exotic birds. Biol Conserv 78: 69-96

263 Cassey P, Blackburn TM, Sol D, Duncan RP, Lockwood JL (2004) Global patterns of 264 introduction effort and the establishment success of birds. Proc R Soc London B (Suppl) 271: s405-s408

Cassey P, Prowse TAA, Blackburn TM (2014) A population model for predicting the successful establishment of introduced bird species. Oecologia 175: 417-428

Christensen GC (1954) The chukar partridge in Nevada. Nevada Fish and Game Commission Biol. Bull No 1.77pp 
270 Christensen GC (1970) The Chukar Partridge: Its introduction, life history, and

271 management. Nevada Dept of Fish and Game Biol Bull No 4. 82 pp

272 Christensen G C (1996) Chukar (Alectoris chukar). In: Poole A, Gill F (Eds) The Birds of

273 North America, No 258. The Academy of Natural Sciences, Philadelphia, PA and the

274 American Ornithologists' Union, Washington DC

275 Diamond JM, Veitch CR (1981) Extinctions and Introductions in the New Zealand Avifauna:

$276 \quad$ Cause and Effect? Science 30 (211): 499 - 501

277 Dickinson EC, Remsen JV Jr (Eds) (2013) The Howard and Moore complete checklist of the

278 birds of the world. 4th edition Vol. 1 Aves Press, Eastbourne U.K.

279 Duncan RP (1997) The role of competition and introductions effort in the success of

280 passeriform birds introduced to New Zealand. Amer Nat 149: 903-915

281 Duncan RP, Blackburn TM, Sol D (2003) The ecology of bird introductions. Annu Rev Ecol

$282 \quad$ Evol and Syst 34: 71-98

283 Gamarra JGP, Montoya JM, Alonso D, Sole RV (2005) Competition and introduction regime

284 shape exotic bird communities in Hawaii. Biol Inv 7: 297-307

285 Green RE (1997) The influence of numbers released on the outcome of attempts to

286 introduce exotic bird species to New Zealand. J Anim Ecol 66: 25-35

287 Griffith B, Scott JM, Carpenter JW, Reed C (1989) Translocation as a species conservation

288 tool: status and strategy. Science 245: 477-480

289 Gullion GW (1965) A critique concerning foreign game bird introductions. Wilson Bulletin

$290 \quad 77: 409-414$

291 Imhof TA (1958) Recent additions to the avifauna of Alabama. Auk 75: 354-357 
292 Imhof TA (1976) Alabama birds, 2ed. Dept of Conservation, Game and Fish Division, 293 University of Alabama Press, Alabama

294 Johnsgard PA (1988) The quails, partridges, and francolins of the world. Oxford University 295 Press, Oxford

296 Leopold A (1931) Report on a game survey of the north central states. Sporting arms and 297 ammunition manufacturers institute, Madison, WI

298 Lever C (1987) Naturalized birds of the world. Longman Sci and Tech, Burnt Hill, Harlow, $299 \quad$ Essex

300 Lever C (2005) Naturalised birds of the world. T \& AD Poyser, London

301 Lockwood JL, Moulton MP, Anderson. SK (1993) Morphological assortment and the 302 assembly of communities of introduced passeriforms on oceanic islands: Tahiti 303 versus Oahu. Amer Natur 141: 398-408

304 Lockwood JL, Cassey P, Blackburn T (2005) The role of propagule pressure in explaining 305 species invasions. Trends in Ecology and Evolution 20: 223-228.

306 Lockwood JL, Moulton MP (1994) Ecomorphological pattern in Bermuda birds: the 307 influence of competition and implications for nature preserves. Evolutionary $308 \quad$ Ecology 8: 53-60

309 Long JL (1981) Introduced birds of the world. David and Charles, London.

310 Moulton MP, Pimm SL (1983) The introduced Hawaiian avifauna: biogeographic evidence 311 for competition. Amer Nat 121: 669-690

312 Moulton MP, Pimm SL (1987) Morphological assortment in introduced Hawaiian 313 passerines. Evol Ecol 1: 113-124. 
314 Moulton MP, Cropper WP Jr, Avery ML, Moulton LE (2010) The earliest House Sparrow

315 introductions of North America. Biological Invasions 12:2955-2958

316 Moulton MP, Cropper WP Jr, Avery ML (2011) A reassessment of the role of propagule

317 pressure in influencing the fates of passerine introductions to New Zealand. Biodiv

318 and Conserv 20: 607-623

319 Moulton MP, Cropper WP Jr, Moulton LE, Avery ML, Peacock D (2012a) A reassessment of

320 historical records of avian introductions to Australia: no case for propagule pressure.

$321 \quad$ Biodiver and Conser 21: 155-174

322 Moulton MP, Cropper WP Jr, Avery ML (2012b) Historical records of passerine

323 introductions to New Zealand fail to support the propagule pressure hypothesis.

324 Biodiversity and Conservation 21: 297-307.

325 Moulton MP, Cropper WP Jr, Avery ML (2013) Is propagule size the critical factor in

326 predicting introduction outcomes in Passeriform birds? Biol Inv 15: 1449-1458.

327 Moulton MP, Cropper WP Jr (2014a) Establishment success in introduced passeriforms of

328 New Zealand: evidence for a Franklin Delano Roosevelt effect. Biol Inv 16: 233-237

329 Moulton MP, Cropper WP Jr (2014b) A comparison of success rates of introduced

330 passeriform birds in New Zealand, Australia and the United States. PeerJ 2:e509

$331 \quad$ http://dx.doi.org/10.7717/peerj.509

332 Moulton MP, Cropper WP Jr (2015) A comment on the role of propagule pressure in the

333 establishment success of introduced birds. Oecologia 177:317-319

334 Newsome AE, Noble IR (1986) Ecological and physiological characters of invading species.

335 In: Groves RH, Burdon JJ (Eds) Ecology of Biological Invasions. Cambridge University

336 Press, Cambridge, pp 1-20 
337 Phillips JC (1928) Wild birds introduced or transplanted in North America. US Dept Ag

$338 \quad$ Tech Bull 61. US Government Printing Office, Washington, DC

339 SAS (2009) SAS/STAT (R) 9.2 User's Guide, Second Edition. SAS Institute Inc., Cary, North $340 \quad$ Carolina

341 Smallwood KS (1994) Site invasibility by exotic birds and mammals. Biological

$342 \quad$ Conservation 69: 251-259.

343 Sol D, Maspons J, Vall-llosera M, Bartomeus I, García-Peña GE, Piñol J, Freckleton RP (2012)

$344 \quad$ Unraveling the Life History of Successful Invaders. Science 37: 580-

345 Thomson GM (1922) The naturalization of plants and animals in New Zealand. Cambridge

346 University Press, Cambridge.

347 Veltman CJ, Nee S, Crawley MJ (1996) Correlates of introduction success in exotic New

$348 \quad$ Zealand birds. Amer Nat 147: 542-557.

349 Watson GE (1962a) Sympatry in Palearctic Alectoris partridges. Evolution 16: 11-19

350 Watson GE (1962b) Three sibling species of Alectoris partridge. Ibis 104: 353-367 
352 Table 1. Chukar releases according to Christensen (Ch 1954, Ch 1970); Lever (1987) and

353 Long (1981). A question mark indicates that the state was mentioned by the source but no

354 propagule information was available. Chukars are considered established in the ten states

355 in italics: Chukars were considered established in 1954 in the 4 italicized states marked

356 with an asterisk.

\begin{tabular}{|c|c|c|c|c|c|c|}
\hline State & $\begin{array}{c}\text { Ch } \\
1954\end{array}$ & $\begin{array}{c}\text { Ch } \\
1970\end{array}$ & $\begin{array}{l}\text { Lever } \\
1987\end{array}$ & $\begin{array}{l}\text { Long } \\
1981\end{array}$ & $\begin{array}{l}\text { Sol et al. } \\
2012\end{array}$ & FGIP \\
\hline Alabama 1 & 720 & 720 & $?$ & $?$ & . & $\theta^{\prime}$ \\
\hline Arizona & 9866 & 11737 & 1133 & 1133 & 1133 & 534 \\
\hline California* & 44554 & 55000 & 75173 & 39186 & 14287 & 11837 \\
\hline Colorado & 10433 & 24080 & 8000 & 9000 & 9000 & . \\
\hline Connecticut & $100 \mathrm{~s}$ & 1500 & . & . & . & . \\
\hline Florida & few & few & $?$ & . & . & . \\
\hline Georgia & . & . & $?$ & . & . & . \\
\hline Idaho* & 8581 & 25710 & 28000 & 28000 & 25000 & . \\
\hline Illinois & 9000 & 9000 & $?$ & . & . & . \\
\hline Indiana & . & 7500 & . & . & . & . \\
\hline Iowa & 1847 & 1847 & . & . & . & . \\
\hline Kansas & 7879 & 7879 & $?$ & $?$ & . & . \\
\hline Kentucky & 1500 & 5480 & $?$ & . & . & . \\
\hline Louisiana & few & few & . & . & . & . \\
\hline Maryland & . & . & $?$ & . & . & . \\
\hline
\end{tabular}




\begin{tabular}{|l|c|c|c|c|c|c|}
\hline Massachusetts & few & 500 & $?$ & $\cdot$ & $\cdot$ & $\cdot$ \\
\hline Michigan & few & few & $?$ & $?$ & $\cdot$ & $\cdot$ \\
\hline Minnesota & 85000 & 85000 & 84414 & 84414 & 84414 & $\cdot$ \\
\hline Mississippi & few & few & $\cdot$ & $\cdot$ & $\cdot$ & $\cdot$ \\
\hline Missouri & 1838 & 1838 & 1900 & 1838 & 1900 & $\cdot$ \\
\hline Montana & 3629 & 7854 & 5365 & 5365 & 5365 & $\cdot$ \\
\hline Nebraska & 14750 & 28142 & 27842 & $?$ & 27842 & 26748 \\
\hline Nevada* & 6399 & 13655 & 5339 & 6739 & 5000 & $\cdot$ \\
\hline New Hampshire & 130 & 130 & $\cdot$ & $\cdot$ & $\cdot$ & $\cdot$ \\
\hline New Mexico & 4943 & 31000 & 16621 & 7700 & $\cdot$ & 16471 \\
\hline New York & & & $<600$ & $<600$ & $175^{\mathrm{B}}$ & \\
\hline North Carolina & 449 & 449 & $\cdot$ & $\cdot$ & $\cdot$ & $\cdot$ \\
\hline North Dakota & 2300 & 5600 & $?$ & $\cdot$ & $\cdot$ & $\cdot$ \\
\hline Ohio & 20 & 20 & $\cdot$ & $\cdot$ & $\cdot$ & $\cdot$ \\
\hline Oklahoma & $1000 \mathrm{~s}$ & $1000 \mathrm{~s}$ & $\cdot$ & $\cdot$ & $\cdot$ & $\cdot$ \\
\hline Oregon & 19898 & 113675 & 76000 & 76000 & 76000 & $\cdot$ \\
\hline Pennsylvania & 2377 & 2377 & 2021 & 2021 & 2021 & $\cdot$ \\
\hline Rhode Island & $\cdot$ & few & $\cdot$ & $\cdot$ & $\cdot$ & $\cdot$ \\
\hline South Carolina & few & $200+$ & $\cdot$ & $\cdot$ & $\cdot$ & $\cdot$ \\
\hline South Dakota & 1459 & 1831 & 1368 & 1368 & 1368 & 75 \\
\hline Tennessee & 5824 & 5824 & $?$ & $?$ & $\cdot$ & $\cdot$ \\
\hline
\end{tabular}




\begin{tabular}{|l|c|c|c|c|c|c|}
\hline Utah & 8666 & 185911 & 458 & $?$ & 515 & 73360 \\
\hline Virginia & 100 & 100 & $\cdot$ & $\cdot$ & $\cdot$ & \\
\hline Washington* & 7041 & 50920 & 64996 & 5841 & 5841 & $59155^{2}$ \\
\hline West Virginia & 4420 & 4429 & $\cdot$ & $\cdot$ & $\cdot$ & $\cdot$ \\
\hline Wisconsin & 43013 & 43013 & 17550 & 17550 & 17550 & $\cdot$ \\
\hline Wyoming & 14000 & 60000 & 17455 & 53455 & 17455 & $\cdot$ \\
\hline & & & & & & \\
\hline States & 37 & 40 & 30 & 22 & $17^{2}$ & 7 \\
\hline Records & 37 & 40 & 69 & 50 & 65 & 154 \\
\hline Individuals & 320636 & 793424 & 451794 & 446788 & 294866 & 188180 \\
\hline
\end{tabular}

357

$358{ }^{1}$ These could have been Rock Partridges. Imhof (1976) listed "Chukars" in one part of his

359 book and "Rock Partridges" in another, and as Alectoris graeca in both places. Moreover he

360 listed the origin of the birds as "southeastern Europe", and did not include the species in a

361 previous publication on birds new to Alabama (Imhof 1958).

$362{ }^{2}$ Includes by assumption (see text) one unidentified report as being from the state of New

363 York, possibly one for Nebraska (Table 2) and excludes a release attributable to Alaska.

$364{ }^{2}$ Of these releases, 51,247 occurred between 1970 and 1978 (Banks 1981). 
366 Table 2. Presumed sources for Sol et al. (2012) records. ID refers to the ID number in Sol

367 et al. (2012); Fate $=1$ successful, $0=$ unsuccessful; Prop = propagule size as listed by Sol et

368 al. (2012). Lever and Long refer to the presence of the record in those two references

369 (Long 1981; Lever 1987): .5 = fewer listed by the reference; $1=$ identical number listed; $2=$

370 additional releases to the state were listed by the reference. The Fates are those Sol et al.

371 (2012) reported (S= Successful; F = Failed).

372

\begin{tabular}{|c|c|c|c|c|c|c|}
\hline ID & Fate & Prop & State & Lever & Long & Fate \\
\hline 81 & 1 & 333 & $\mathrm{AZ}$ & 1 & 1 & $\mathrm{~S}$ \\
\hline 3204 & 1 & 800 & $\mathrm{AZ}$ & 1 & 1 & $\mathrm{~S}$ \\
\hline 53 & 1 & 4600 & $\mathrm{CA}$ & 1 & 1 & $\mathrm{~S}$ \\
\hline 3197 & 1 & 423 & $\mathrm{CA}$ & $\cdot$ & 1 & $\mathrm{~S}$ \\
\hline 3198 & 1 & 444 & $\mathrm{CA}$ & $\cdot$ & 1 & $\mathrm{~S}$ \\
\hline 3199 & 1 & 440 & $\mathrm{CA}$ & $\cdot$ & 1 & $\mathrm{~S}$ \\
\hline 3200 & 1 & 440 & $\mathrm{CA}$ & $\cdot$ & 1 & $\mathrm{~S}$ \\
\hline 3201 & 1 & 440 & $\mathrm{CA}$ & $\cdot$ & 1 & $\mathrm{~S}$ \\
\hline 3202 & 1 & 7000 & $\mathrm{CA}$ & 1 & 1 & $\mathrm{~S}$ \\
\hline 3203 & 1 & 500 & $\mathrm{CA}$ & $\cdot$ & 1 & $\mathrm{~S}$ \\
\hline 3205 & 1 & 9000 & $\mathrm{CO}$ & 1 & .5 & $\mathrm{~S}$ \\
\hline 82 & 1 & 25000 & $\mathrm{ID}$ & 1 & 1 & $\mathrm{~S}$ \\
\hline 59 & 0 & 84414 & $\mathrm{MN}$ & 1 & 1 & $\mathrm{~F}$ \\
\hline 60 & 0 & 1900 & $\mathrm{MO}$ & 1 & .5 & $\mathrm{~F}$ \\
\hline
\end{tabular}




\begin{tabular}{|c|c|c|c|c|c|c|}
\hline 771 & 1 & 5365 & MT & 1 & 1 & $\mathrm{~S}$ \\
\hline 1897 & 0 & 27842 & $\mathrm{NE}$ & 1 & $?$ & $\mathrm{~F}$ \\
\hline 84 & 1 & 5000 & NV & 2 & 2 & $\mathrm{~S}$ \\
\hline 61 & 0 & 175 & NY? & 2 & 2 & $\mathrm{~F}$ \\
\hline 475 & 1 & 76000 & OR & 1 & 1 & $\mathrm{~S}$ \\
\hline 62 & 0 & 2021 & PA & 1 & 1 & $\mathrm{~F}$ \\
\hline 1898 & 1 & 1368 & SD & 1 & 1 & $S$ \\
\hline 88 & 0 & 50 & UT & 1 & . & $\mathrm{F}$ \\
\hline 85 & 0 & 13 & UT & 1 & . & $\mathrm{F}$ \\
\hline 86 & 0 & 23 & UT & 1 & . & $\mathrm{F}$ \\
\hline 87 & 0 & 50 & UT & 1 & . & $F$ \\
\hline 90 & 0 & $41^{*}$ & UT? & 2 & . & $\mathrm{F}$ \\
\hline 91 & 0 & 28 & UT & 1 & . & $\mathrm{F}$ \\
\hline 92 & 0 & 15 & UT & 1 & . & $\mathrm{F}$ \\
\hline 93 & 0 & 15 & UT & 1 & . & $\mathrm{F}$ \\
\hline 94 & 0 & 38 & UT & 1 & r & $\mathrm{F}$ \\
\hline 95 & 0 & 100 & UT & 1 & . & $F$ \\
\hline 96 & 0 & 8 & UT & 1 & . & $\mathrm{F}$ \\
\hline 98 & 0 & 8 & UT & 1 & . & $\mathrm{F}$ \\
\hline 97 & 0 & 50 & UT & 1 & r. & $\mathrm{F}$ \\
\hline 99 & 0 & 76 & UT & 1 & . & $\mathrm{F}$ \\
\hline 1587 & 1 & 5841 & WA & 2 & . & $\mathrm{S}$ \\
\hline
\end{tabular}




\begin{tabular}{|c|c|c|c|c|c|c|}
\hline 467 & 0 & 17550 & WI & 1 & 1 & F \\
\hline 100 & 1 & 17455 & WY & 1 &. & S \\
\hline
\end{tabular}

373

$374 *$ ID 90 of Sol et al. (2012) might be a typographical error, as Lever (1987) listed a release 375 of 46 to Utah.

376 
377 Table 3. Chukar release summary by various sources: Ch70 = Christensen (1970); Le87 =

378 Lever (1987); Lo81 = (Long 1981); Sol = Sol et al. (2012).

379

\begin{tabular}{|c|c|c|c|c|}
\hline State & Ch70 & Le87 & Lo81 & Sol \\
\hline Nevada & 13655 & 5339 & 6739 & 5000 \\
\hline California & 55000 & 75173 & 39186 & 14287 \\
\hline Colorado & 24080 & 8000 & 9000 & 9000 \\
\hline Wyoming & 60000 & 17455 & 53455 & 17455 \\
\hline Idaho & 25710 & 28000 & 28000 & 25000 \\
\hline Washington & 50920 & 64996 & 5841 & 5841 \\
\hline Arizona & 11737 & 1133 & 1133 & 1133 \\
\hline South Dakota & 1831 & 1368 & 1368 & 1368 \\
\hline Missouri & 1838 & 1900 & 1838 & 1900 \\
\hline Pennsylvania & 2377 & 2021 & 2021 & 2021 \\
\hline Montana & 7854 & 5365 & 5365 & 5365 \\
\hline Wisconsin & 43013 & 17550 & 17550 & 17550 \\
\hline Oregon & 113675 & 76000 & 76000 & 76000 \\
\hline Minnesota & 85000 & 84414 & 84414 & 84414 \\
\hline New Mexico & 31000 & 16621 & 7700 & . \\
\hline Utah & 185911 & 458 & . & 515 \\
\hline Nebraska & 28142 & 27842 & . & 27842 \\
\hline New York & . & $<600$ & $<600$ & $175 ?$ \\
\hline
\end{tabular}


381 Figure 1. Number of states reporting total numbers of Chukars released: Christensen

382 (1970); Lever (1987); Long (1981).

383

384

385 


\section{Figure 1 (on next page)}

\section{Figure 1}

Number of states reporting total numbers of Chukars released: Christensen (1970); Lever (1987); Long (1981). 


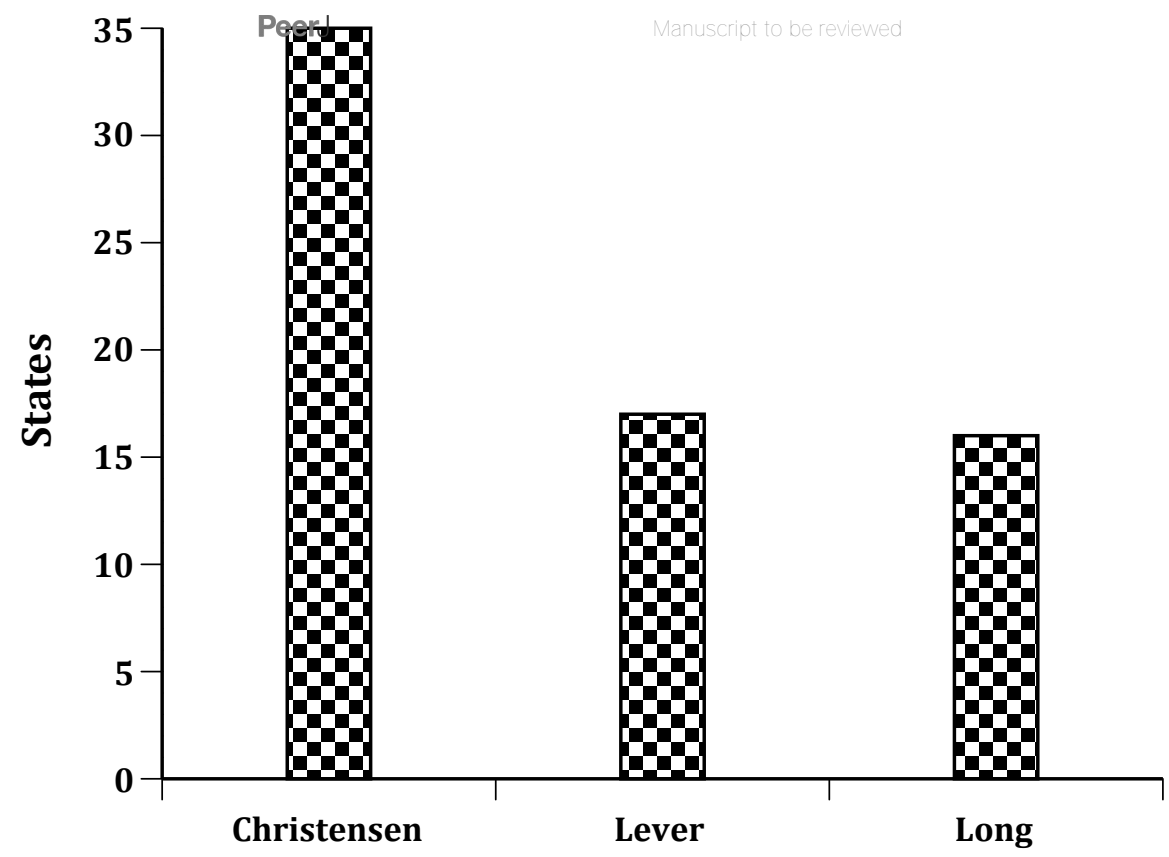

Reference 


\section{Table $\mathbf{1}$ (on next page)}

Table 1

Chukar releases according to Christensen (Ch 1954, Ch 1970); Lever (1987) and Long (1981).

A question mark indicates that the state was mentioned by the source but no propagule information was available. Chukars are considered established in the ten states in italics: Chukars were considered established in 1954 in the 4 italicized states marked with an asterisk. 
1 Table 1. Chukar releases according to Christensen (Ch 1954, Ch 1970); Lever (1987) and

2 Long (1981). A question mark indicates that the state was mentioned by the source but no

3 propagule information was available. Chukars are considered established in the ten states

4 in italics: Chukars were considered established in 1954 in the 4 italicized states marked

5 with an asterisk.

\begin{tabular}{|c|c|c|c|c|c|c|}
\hline State & $\begin{array}{c}\text { Ch } \\
1954\end{array}$ & $\begin{array}{c}\text { Ch } \\
1970\end{array}$ & $\begin{array}{l}\text { Lever } \\
1987\end{array}$ & $\begin{array}{l}\text { Long } \\
1981\end{array}$ & $\begin{array}{l}\text { Sol et al. } \\
2012\end{array}$ & FGIP \\
\hline Alabama $^{1}$ & 720 & 720 & $?$ & $?$ & . & . \\
\hline Arizona & 9866 & 11737 & 1133 & 1133 & 1133 & 534 \\
\hline California* & 44554 & 55000 & 75173 & 39186 & 14287 & 11837 \\
\hline Colorado & 10433 & 24080 & 8000 & 9000 & 9000 & . \\
\hline Connecticut & $100 s$ & 1500 & . & $\cdot$ & . & . \\
\hline Florida & few & few & $?$ & . & . & . \\
\hline Georgia & • & . & $?$ & . & . & . \\
\hline Idaho* & 8581 & 25710 & 28000 & 28000 & 25000 & . \\
\hline Illinois & 9000 & 9000 & $?$ & . & . & . \\
\hline Indiana & & 7500 & . & r & . & . \\
\hline Iowa & 1847 & 1847 & . & . & . & . \\
\hline Kansas & 7879 & 7879 & $?$ & $?$ & . & . \\
\hline Kentucky & 1500 & 5480 & $?$ & . & . & . \\
\hline Louisiana & few & few & . & . & . & . \\
\hline Maryland & . & . & $?$ & . & . & . \\
\hline
\end{tabular}




\begin{tabular}{|l|c|c|c|c|c|c|}
\hline Massachusetts & few & 500 & $?$ & $\cdot$ & $\cdot$ & $\cdot$ \\
\hline Michigan & few & few & $?$ & $?$ & $\cdot$ & $\cdot$ \\
\hline Minnesota & 85000 & 85000 & 84414 & 84414 & 84414 & $\cdot$ \\
\hline Mississippi & few & few & $\cdot$ & $\cdot$ & $\cdot$ & $\cdot$ \\
\hline Missouri & 1838 & 1838 & 1900 & 1838 & 1900 & $\cdot$ \\
\hline Montana & 3629 & 7854 & 5365 & 5365 & 5365 & $\cdot$ \\
\hline Nebraska & 14750 & 28142 & 27842 & $?$ & 27842 & 26748 \\
\hline Nevada* & 6399 & 13655 & 5339 & 6739 & 5000 & $\cdot$ \\
\hline New Hampshire & 130 & 130 & $\cdot$ & $\cdot$ & $\cdot$ & $\cdot$ \\
\hline New Mexico & 4943 & 31000 & 16621 & 7700 & $\cdot$ & 16471 \\
\hline New York & & & $<600$ & $<600$ & $175^{\mathrm{B}}$ & \\
\hline North Carolina & 449 & 449 & $\cdot$ & $\cdot$ & $\cdot$ & $\cdot$ \\
\hline North Dakota & 2300 & 5600 & $?$ & $\cdot$ & $\cdot$ & $\cdot$ \\
\hline Ohio & 20 & 20 & $\cdot$ & $\cdot$ & $\cdot$ & $\cdot$ \\
\hline Oklahoma & $1000 \mathrm{~s}$ & $1000 \mathrm{~s}$ & $\cdot$ & $\cdot$ & $\cdot$ & $\cdot$ \\
\hline Oregon & 19898 & 113675 & 76000 & 76000 & 76000 & $\cdot$ \\
\hline Pennsylvania & 2377 & 2377 & 2021 & 2021 & 2021 & $\cdot$ \\
\hline Rhode Island & $\cdot$ & few & $\cdot$ & $\cdot$ & $\cdot$ & $\cdot$ \\
\hline South Carolina & few & $200+$ & $\cdot$ & $\cdot$ & $\cdot$ & $\cdot$ \\
\hline South Dakota & 1459 & 1831 & 1368 & 1368 & 1368 & 75 \\
\hline Tennessee & 5824 & 5824 & $?$ & $?$ & $\cdot$ & $\cdot$ \\
\hline
\end{tabular}




\begin{tabular}{|l|c|c|c|c|c|c|}
\hline Utah & 8666 & 185911 & 458 & $?$ & 515 & 73360 \\
\hline Virginia & 100 & 100 & $\cdot$ & $\cdot$ & $\cdot$ & \\
\hline Washington* & 7041 & 50920 & 64996 & 5841 & 5841 & $59155^{2}$ \\
\hline West Virginia & 4420 & 4429 & $\cdot$ & $\cdot$ & $\cdot$ & $\cdot$ \\
\hline Wisconsin & 43013 & 43013 & 17550 & 17550 & 17550 & $\cdot$ \\
\hline Wyoming & 14000 & 60000 & 17455 & 53455 & 17455 & $\cdot$ \\
\hline & & & & & & \\
\hline States & 37 & 40 & 30 & 22 & $17^{2}$ & 7 \\
\hline Records & 37 & 40 & 69 & 50 & 65 & 154 \\
\hline Individuals & 320636 & 793424 & 451794 & 446788 & 294866 & 188180 \\
\hline
\end{tabular}

6

$7 \quad{ }^{1}$ These could have been Rock Partridges. Imhof (1976) listed "Chukars" in one part of his

8 book and "Rock Partridges" in another, and as Alectoris graeca in both places. Moreover he

9 listed the origin of the birds as "southeastern Europe", and did not include the species in a

10 previous publication on birds new to Alabama (Imhof 1958).

$11{ }^{2}$ Includes by assumption (see text) one unidentified report as being from the state of New

12 York, possibly one for Nebraska (Table 2) and excludes a release attributable to Alaska.

$13{ }^{2}$ Of these releases, 51,247 occurred between 1970 and 1978 (Banks 1981). 


\section{Table 2 (on next page)}

Table 2

Presumed sources for Sol et al. (2012) records. ID refers to the ID number in Sol et al. (2012);

Fate $=1$ successful, $0=$ unsuccessful; Prop $=$ propagule size as listed by Sol et al. (2012). Lever and Long refer to the presence of the record in those two references (Long 1981; Lever 1987): $.5=$ fewer listed by the reference; $1=$ identical number listed; $2=$ additional releases to the state were listed by the reference. The Fates are those Sol et al. (2012) reported (S= Successful; $F=$ Failed). 
1 Table 2. Presumed sources for Sol et al. (2012) records. ID refers to the ID number in Sol

2 et al. (2012); Fate = 1 successful, $0=$ unsuccessful; Prop = propagule size as listed by Sol et

3 al. (2012). Lever and Long refer to the presence of the record in those two references

4 (Long 1981; Lever 1987): .5 = fewer listed by the reference;1= identical number listed; $2=$

5 additional releases to the state were listed by the reference. The Fates are those Sol et al.

6 (2012) reported (S= Successful; F = Failed).

7

\begin{tabular}{|c|c|c|c|c|c|c|}
\hline ID & Fate & Prop & State & Lever & Long & Fate \\
\hline 81 & 1 & 333 & $\mathrm{AZ}$ & 1 & 1 & $\mathrm{~S}$ \\
\hline 3204 & 1 & 800 & $\mathrm{AZ}$ & 1 & 1 & $\mathrm{~S}$ \\
\hline 53 & 1 & 4600 & $\mathrm{CA}$ & 1 & 1 & $\mathrm{~S}$ \\
\hline 3197 & 1 & 423 & $\mathrm{CA}$ & $\cdot$ & 1 & $\mathrm{~S}$ \\
\hline 3198 & 1 & 444 & $\mathrm{CA}$ & $\cdot$ & 1 & $\mathrm{~S}$ \\
\hline 3199 & 1 & 440 & $\mathrm{CA}$ & $\cdot$ & 1 & $\mathrm{~S}$ \\
\hline 3200 & 1 & 440 & $\mathrm{CA}$ & $\cdot$ & 1 & $\mathrm{~S}$ \\
\hline 3201 & 1 & 440 & $\mathrm{CA}$ & $\cdot$ & 1 & $\mathrm{~S}$ \\
\hline 3202 & 1 & 7000 & $\mathrm{CA}$ & 1 & 1 & $\mathrm{~S}$ \\
\hline 3203 & 1 & 500 & $\mathrm{CA}$ & $\cdot$ & 1 & $\mathrm{~S}$ \\
\hline 3205 & 1 & 9000 & $\mathrm{CO}$ & 1 & .5 & $\mathrm{~S}$ \\
\hline 82 & 1 & 25000 & $\mathrm{ID}$ & 1 & 1 & $\mathrm{~S}$ \\
\hline 59 & 0 & 84414 & $\mathrm{MN}$ & 1 & 1 & $\mathrm{~F}$ \\
\hline 60 & 0 & 1900 & $\mathrm{MO}$ & 1 & .5 & $\mathrm{~F}$ \\
\hline
\end{tabular}




\begin{tabular}{|c|c|c|c|c|c|c|}
\hline 771 & 1 & 5365 & MT & 1 & 1 & $\mathrm{~S}$ \\
\hline 1897 & 0 & 27842 & $\mathrm{NE}$ & 1 & $?$ & $\mathrm{~F}$ \\
\hline 84 & 1 & 5000 & NV & 2 & 2 & $\mathrm{~S}$ \\
\hline 61 & 0 & 175 & NY? & 2 & 2 & $\mathrm{~F}$ \\
\hline 475 & 1 & 76000 & OR & 1 & 1 & $\mathrm{~S}$ \\
\hline 62 & 0 & 2021 & PA & 1 & 1 & $\mathrm{~F}$ \\
\hline 1898 & 1 & 1368 & SD & 1 & 1 & $S$ \\
\hline 88 & 0 & 50 & UT & 1 & . & $\mathrm{F}$ \\
\hline 85 & 0 & 13 & UT & 1 & . & $\mathrm{F}$ \\
\hline 86 & 0 & 23 & UT & 1 & . & $\mathrm{F}$ \\
\hline 87 & 0 & 50 & UT & 1 & . & $F$ \\
\hline 90 & 0 & $41^{*}$ & UT? & 2 & . & $\mathrm{F}$ \\
\hline 91 & 0 & 28 & UT & 1 & . & $\mathrm{F}$ \\
\hline 92 & 0 & 15 & UT & 1 & . & $\mathrm{F}$ \\
\hline 93 & 0 & 15 & UT & 1 & . & $\mathrm{F}$ \\
\hline 94 & 0 & 38 & UT & 1 & r & $\mathrm{F}$ \\
\hline 95 & 0 & 100 & UT & 1 & . & $F$ \\
\hline 96 & 0 & 8 & UT & 1 & . & $\mathrm{F}$ \\
\hline 98 & 0 & 8 & UT & 1 & . & $\mathrm{F}$ \\
\hline 97 & 0 & 50 & UT & 1 & r. & $\mathrm{F}$ \\
\hline 99 & 0 & 76 & UT & 1 & . & $\mathrm{F}$ \\
\hline 1587 & 1 & 5841 & WA & 2 & . & $\mathrm{S}$ \\
\hline
\end{tabular}




\begin{tabular}{|c|c|c|c|c|c|c|}
\hline 467 & 0 & 17550 & WI & 1 & 1 & F \\
\hline 100 & 1 & 17455 & WY & 1 & $\cdot$ & S \\
\hline
\end{tabular}

8

9 * ID 90 of Sol et al. (2012) might be a typographical error, as Lever (1987) listed a release

10 of 46 to Utah.

11 


\section{Table 3(on next page)}

Table 3

Chukar release summary by various sources: Ch70 $=$ Christensen (1970); Le87 $=$ Lever (1987); Lo81 = (Long 1981); Sol = Sol et al. (2012). 
1 Table 3. Chukar release summary by various sources: Ch70 = Christensen (1970); Le87 =

2 Lever (1987); Lo81 = (Long 1981); Sol = Sol et al. (2012).

3

\begin{tabular}{|c|c|c|c|c|}
\hline State & Ch70 & Le87 & Lo81 & Sol \\
\hline Nevada & 13655 & 5339 & 6739 & 5000 \\
\hline California & 55000 & 75173 & 39186 & 14287 \\
\hline Colorado & 24080 & 8000 & 9000 & 9000 \\
\hline Wyoming & 60000 & 17455 & 53455 & 17455 \\
\hline Idaho & 25710 & 28000 & 28000 & 25000 \\
\hline Washington & 50920 & 64996 & 5841 & 5841 \\
\hline Arizona & 11737 & 1133 & 1133 & 1133 \\
\hline South Dakota & 1831 & 1368 & 1368 & 1368 \\
\hline Missouri & 1838 & 1900 & 1838 & 1900 \\
\hline Pennsylvania & 2377 & 2021 & 2021 & 2021 \\
\hline Montana & 7854 & 5365 & 5365 & 5365 \\
\hline Wisconsin & 43013 & 17550 & 17550 & 17550 \\
\hline Oregon & 113675 & 76000 & 76000 & 76000 \\
\hline Minnesota & 85000 & 84414 & 84414 & 84414 \\
\hline New Mexico & 31000 & 16621 & 7700 & . \\
\hline Utah & 185911 & 458 & . & 515 \\
\hline Nebraska & 28142 & 27842 & . & 27842 \\
\hline New York & & $<600$ & $<600$ & $175 ?$ \\
\hline
\end{tabular}


